\title{
RANCANG BANGUN JARINGAN KOMPUTER LAN BERDASARKAN PERBANDINGAN KINERJA ROUTING PROTOKOL EIGRP DAN ROUTING PROTOKOL OSPF
}

\author{
Lalu Zazuli Azhar Mardedi ${ }^{1}$, Khairan Marzuki ${ }^{2}$ \\ ${ }^{1,2}$ Universitas Bumigora Mataram \\ ${ }^{1}$ Email : zazuli@stmikbumigora.ac.id, ${ }^{2}$ Email : khairanmarzuki@gmail.com
}

\begin{abstract}
ABSTRAK
Saat ini jaringan komputer sangat berkembang pesat dan penggunaan internet setiap hari semakit meningkat. Kebutuhan dalam merancang jaringan internet tidak lepas dari routing protocol yang berfungsi untuk mengintegrasikan semua komputer dengan fleksibilitas tertinggi. Routing salah satu bagian yang memberikan kinerja yang efektif dalam jaringan. Dalam mengetahui perbandingan kinerja routing protocol EIGRP maupun $O S P F$, penerapan EIGRP dan OSPF harus diimplementasikan ketika membangun jaringan maka administrator dengan mudahnya mengetahui perbedaan nilai kinerja dari kedua routing protocol tersebut. Pembahasan dalam penelitian ini yaitu mengetahui perbandingan kinerja routing protocol EIGRP dan routing protocol OSPF yang berada pada jaringan dengan menggunakan topologi hybird. Mengatasi permasalahan pada akses jaringan yang berskala tinggi maka akan dilakukan analisis dan perbandingan kinerja antara routing protocol EIGRP dengan routing protocol $O S P F$. Dalam memperoleh nilai dan untuk memverifikasi hasil pelaksanaan maka simulasi perangkat lunak menggunakan simulator Packet Tracer.
\end{abstract}

Kata kunci: EIGRP, OSPF, simulator, kinerja, Packet Tracer.

\section{ABSTRACT}

Nowadays computer networks are growing rapidly and internet usage is increasing everyday. The need to design an internet network cannot be separated from the routing protocol which functions to integrate all computers with the highest flexibility. Routing is one part that provides effective performance in the network. In comparing the performance of EIGRP and OSPF routing protocols, the implementation of EIGRP and OSPF must be implemented when building a network, so administrators easily know the difference in the performance values of the two routing protocols. The discussion in this study is to compare the performance of the EIGRP routing protocol and OSPF routing protocol that is on the network using the hybird topology. Overcoming problems with high-scale network access, we will analyze and compare performance between EIGRP routing protocol and OSPF routing protocol. In obtaining the value and to verify the results of the implementation, the simulation software uses a Packet Tracer simulator.

Keywords: EIGRP, OSPF, simulator, performance, Packet Tracer.

\section{PENDAHULUAN}

Implementasi dan manfaat internet didunia industry maupun birokrasi pemerintahan dan swasta semakin meningkat penggunaannya. Proses ini yang memberikan segala bentuk kemudahan yang diberikan oleh internet, kemudahan tersebut meliputi pelaksanaan komunikasi data menjadi cepat dan efisien. Membangun internet sekaligus untuk implementasi tentunya semua kebutuhan harus terpenuhi seperti perangkat hardware maupun software. Perangkat hardware yang dikmaksud yaitu perangkat router, cable, connector dan switch serta komputer sehingga dengan mudah dan tepatnya dalam menyusun kerangka jaringan dan internet. Dalam pembangunan jaringan internet terlebih dahulu harus memahami teknik pengalamatan IP address serta teknik untuk merouting. Paket data yang dikirim dari tempat asal (host) kemudian dilanjutkan ke penerima atau tujuan (host) merupakan fungsi dari pada router.[1]

Layanan internet sangat bermanfaat bagi perusahaan swasta maupun negeri karena sangat membantu dalam pengolahan dan komunikasi data. Upaya dalam pembangunan internet tidak terlepas dari kebutuhan perangkat hardware, perangkat software, dan protocol. Protocol 
standar yang diimplementasikan pada internet yaitu $T C P / I P$ dimana penerapannya sangat penting dan berpengaruh terhadap sistem kerja pada router. Sistem kerja seperti ini yang menyebabkan jumlah host meningkat terutama sering sekali terjadi pemakaian perangkat $T C P / I P$ yang berbeda yang digunakan. Untuk menangani kebutuhan implementasi tersebut maka dengan penerapan routing pada jaringan internet sangat tepat sehingga dapat memberikan penanganan komputer yang banyak dengan tingkat fleksibilitas tinggi. Routing itu sendiri dikelompokkan menjadi dua bagian seperti routing dinamis dan statis.[2]

Membangun jaringan komputer yang terhubung ke internet dibutuhkan strategi yang matang berdasarkan referensi perbandingan kinerja antara Routing Protocol EIGRP dan Routing Protocol OSPF dilihat dari segi mana yang lebih baik, agar setiap pengguna memperoleh pelayanan yang efektif dalam melakukan komunikasi data ke internet dengan mendapatkan pelayanan akses internet yang terbaik. Routing Protocol EIGRP dan OSPF pada saat ini sangat diunggulkan karena keduanya memiliki kinerja yang baik dan efektif dalam meroutekan jaringan internet.[3] Untuk mengetahui efektivitas pembagian bandwith maka akan dibahas tentang perbandingan kinerja yang lebih baik antara Routing Protocol EIGRP dan Routing Protocol OSPF. Agar menghasilkan sistem jaringan yang memuaskan bagi pengguna karena memiliki pelayanan akses yang terbaik yang dapat diimplementasikan terhadap jaringan yang terhubung ke internet.

Local Area Network adalah jaringan yang dibatasi oleh area yang relative kecil, umumnya diabatasi oleh area lingkungan seperti sebuah perkantoran disebuah gedung, atau sebuah sekolah, dan biasanya tidak jauh dari $1 \mathrm{~km}$ persegi.[2]

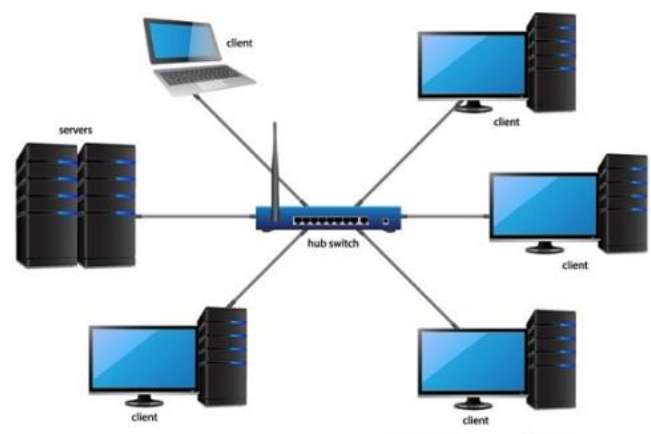

Gambar 1. Topologi Local Area Network
Routing protocol adalah seperangkat aturan atau standar yang menentukan bagaimana router pada jaringan berkomunikasi dan bertukar informasi satu sama lain, memungkinkan mereka untuk memilih rute terbaik pada jaringan yang dituju. Routing protocol melakukan beberapa kegiatan, termasuk :

a. Network discovery

b. Memperbaharui dan melakukan maintenance terhadap routing table.

Metode yang sering diimplementasikan oleh routing protocol sebagai berikut :

a. Distance Vector (Path Vector) Protocol

Disebut distance vector protocol karena menentukan routing berdasarkan distance atau jarak terdekat, diantara tempat paket asal ketempat paket tujuan.[2]

b. Link State Protocol

Disebut link state protocol karena pengambilan routing berdasarkan informasi yang diperoleh dari router-router yang lain. Selanjutnya akan dilakukan penentuan routing sesuai dengan informasi.[2]

c. Ring

Protocol ring memakai aspek-aspek dari routing protocol jenis distance vector dan link state. Contoh ring adalah EIGRP. [2]

Routing protocol Open Shortest Path First (OSPF) atau Link-State (LS) dalam penerapannya berdasarkan open standard. Setiap router yang dikonfigurasikan dengan menggunakan link-state routing protocol akan mengirimkan dua macam paket, yaitu :

a. LSR (Link-State Refreshment) yang dikirimkan secara periodik ke router yang berada disekitarnya untuk mengetahui apakah router tersebut masih aktif dan masih terbentuk link ke router tersebut.

b. LSA (Link-State Advertisement) atau routing update, yang dikirimkan hanya pada saat ada perubahan pada jaringan dan pada saat awal (inisialisasi).

c. Delay adalah waktu yang dibutuhkan oleh sebuah paket data terhitung dari saat pengiriman oleh transmitter sampai saat diterima oleh receiver.[3]

Pada awal OSPF router dihidupkan, maka router akan mengirimkan LSA secara multicast. Router yang menerima LSA, akan menyalin informasi yang dibawanya, kemudian 
meneruskan (forward) LSA tersebut. Informasi yang diperoleh dari LSA akan disimpan pada topological (link-state) database. Berdasarkan LSA dan juga topological database yang berisi semua router yang ada pada jaringan tersebut, maka setiap router akan menjalankan SPF algoritma dan membentuk SPF Tree.[1]

Routing protocol milik cisco yang bekerja pada router Cisco dan pada prosesor-prosesor route internal yang terdapat pada switch layer core dan switch layer distribusi Cisco. Enhanced Interior Gateway Routing Protocol (EIGRP) merupakan protocol distance vector yang classes dan yang sudah ditingkatkan.

EIGRP memiliki karakteristik sebagai berikut :

a. Menggunakan cost load balancing yang tidak sama.

b. Distance vector dan lingk-state merupakan suatu kombinasi dalam memakai dan menerapkan algorithm.

c. Menggunakan Diffusing Update Algoritma (DUAL) untuk menghitung jalur terpendek.

d. Mendukung IP, IPX, dan AppleTalk melalui modul-modul yang bersifat protcocol dependent.[2]

\section{METODOLOGI}

\section{Metode Pengembangan}

Adapun bagian dan tahapan yang dilakukan dalam metode pengembangan adalah sebagai berikut :

a. Analisis kebutuhan

Proses mengidentifikasi masalah sehingga menghasilkan cara untuk melakukan alternative pemecahan yang efektif.

b. Rancangan

Dalam pembangunan suatu sistem langkah pertama yang dilakukan yaitu perancangan sistem karena akan menghasilkan desain sistem yang dibangun. Tahapan ini juga terdapat fase proses pembuatan, pengembangan sistem untuk semua jenis produk sistem.

c. Modeling

Desain sistem yang sudah dibuat berdasarkan hasil rancangan diatas maka pada tahapan ini akan lebih mudah melakukan proses aplikasi desain dengan skala terbatas dan menjadi karya yang bermanfaat.

d. Pengujian

Aplikasi yang proses pengerjaannya sudah sampai batas akhir pembuatan maka selanjutnya penulis akan melakukan tahapan uji coba desain dan model sistem sehingga penulis mengetahui hasil akhir dari sebuah permasalahan yang disesuaikan.

\section{Teknik Pengumpulan Data}

a. Triangulasi

Melakukan proses mengumpulkan informasi yang diambil melalui sumber data secara berbeda-beda dengan mengambil data dan juga mendapatkan hasil pengujian terhadap keaslian data dengan cara melihat, membaca, membandingkan dan mengecek keaslian data dengan semua sumber data.

b. Literatur

Melakukan pengumpulan informasi yang relevan yang didapat melalui literature buku, internet dan karya ilmiah lainnya seperti jurnal ilmiah, tesis dan disertasi. Hasil mengumpulkan informasi yang diperoleh yaitu jaringan internet yang memiliki suatu kondisi, menggunakan data jaringan internet, jaringan internet tentang proses mengamati parameter traffic seperti delay dan waktu konvergensi, rencana pembangunan jaringan komputer.

\section{Tahapan Desain Rancangan}

Kebutuhan akan implementasi jaringan yang dapat berbeda-beda disetiap lokasi membuat perbedaan pada jenis dan jumlah alat yang dibutuhkan. Perbedaan jenis dan jumlah alat ini pula yang pada akhirnya membuat terjadinya perbedaan pada teknik serta metode untuk mendapatkan informasi yang diperlukan oleh router, sebagai salah satu alat untuk proses routing di jaringan. Penggunaan banyak router membuat network administrator memilih untuk menggunakan routing protocol sebagai cara bagi router untuk mendapatkan informasi untuk melakukan routing.

a. Flowchart Perancangan Jaringan

Dalam penelitian ini dijelaskan cara perancangan sistem dan konfigurasi simulasi pengiriman paket data berdasarkan penggunaan dari routing protocol EIGRP dan OSPF dengan pemanfaatan topologi ring. Flowchart rancangan jaringan seperti pada gambar dibawah ini: 


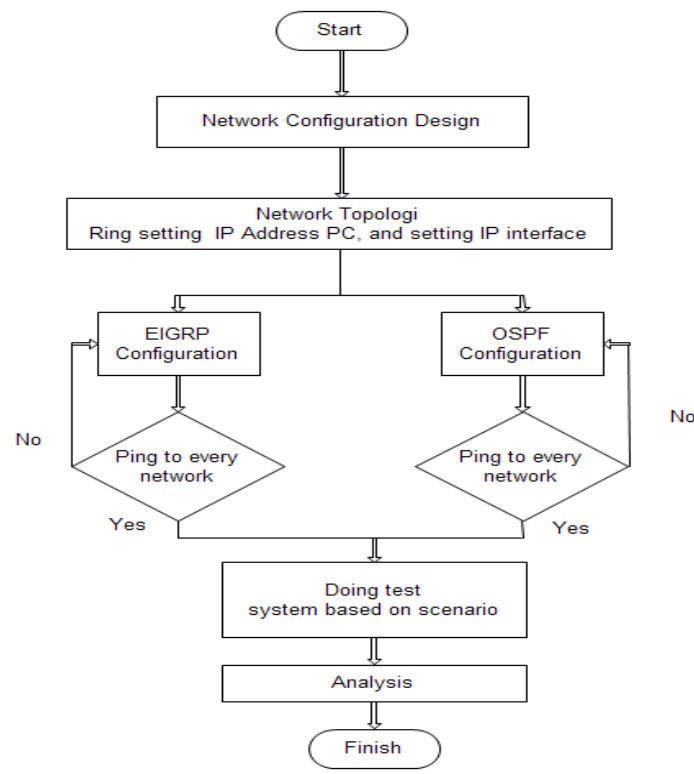

Gambar 2. Flowchart perancangan jaringan.

Gambar 2 menunjukkan tahapan dalam perancangan dan simulasi kinerja dari routing protocol EIGRP dan routing protocol OSPF pada topologi ring. Simulasi ini dilakukan pada perangkat lunak Packet Tracer dan dimulai dengan mengkonfigurasi jaringan lalu pembuatan topologi jaringan yaitu topologi ring, setting IP Address, dan setting IP pada setiap interface. Masing-masing topologi dikonfigurasi oleh routing protocol EIGRP dan routing protocol OSPF kemudian dilakukan tes ping kesetiap $P C$ yang ada setelah berhasil maka dilanjutkan terhadap analisis.

\section{b. Topologi Jaringan}

Perangkat lunak yang digunakan untuk simulator yaitu Paket Tracer menyediakan lingkungan pengembangan kinerja jaringan komunikasi. Pada rancangan ini akan diterapkan satu backbone yang digunakan oleh dua Perguruan Tinggi yaitu Akademi Manajemen Informatika Komputer dan Akademi Sekretari dan Manajemen Mataram. Jaringan yang ingin diimplementasikan hanya membandingkan kinerja dari routing protocol EIGRP dengan routing protocol $O S P F$.

Topologi ring merupakan topologi yang digunakan dalam simulator dengan penggunaan perangkat dan alat jaringan seperti perangkat router, perangkat switch, dan komputer PC, semua perangkat ini akan dijadikan alat untuk membangun simulator dengan desain perancangna menggunakan perangkat lunak
Packet Tracer. Desain topologi jaringan seperti gambar dibawah ini :

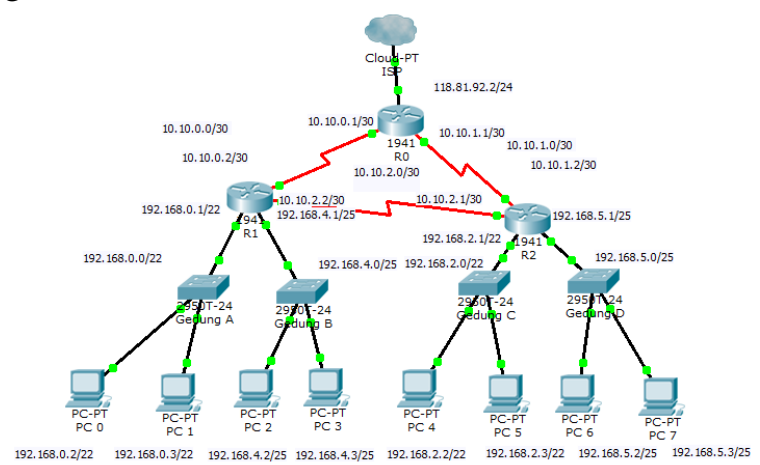

Gambar 3. Topologi jaringan

\section{Perhitungan IP Address}

Pada tahap ini akan dilakukan subnetting berdasarkan jumlah jaringan yang ada sebanyak 7 jaringan yaitu dari R0 ke R1, R0 ke R2, R1 ke R2, jaringan Gedung A, jaringan Gedung B, jaringan Gedung $\mathrm{C}$ dan jaringan Gedung $\mathrm{D}$. Adapun network address masing-masing jaringan adalah sebagai berikut:

Tabel 1. Network address

\begin{tabular}{|l|l|}
\hline Network Name & Network Address \\
\hline R0 ke R1 & $10.10 .0 .0 / 30$ \\
\hline R0 ke R2 & $10.10 .1 .0 / 30$ \\
\hline R1 ke R2 & $10.10 .2 .0 / 30$ \\
\hline Jaringan Gedung A & $192.168 .0 .0 / 22$ \\
\hline Jaringan Gedung B & $192.168 .4 .0 / 25$ \\
\hline Jaringan Gedung C & $192.168 .2 .0 / 22$ \\
\hline Jaringan Gedung D & $192.168 .5 .0 / 25$ \\
\hline
\end{tabular}

Tabel 2. Perhitungan IP address

\begin{tabular}{|c|c|c|c|c|}
\hline $\begin{array}{l}\text { Nom } \\
\text { or } \\
\text { Subn } \\
\text { et }\end{array}$ & $\begin{array}{c}\text { IP Address } \\
\text { yang } \\
\text { tersedia }\end{array}$ & $\begin{array}{c}\text { Address } \\
\text { Networ } \\
\text { k }\end{array}$ & $\begin{array}{c}\text { Address } \\
\text { Broadcast }\end{array}$ & Subnetmask \\
\hline SN 1 & $\begin{array}{l}10.10 .0 .1- \\
10.0 .0 .2\end{array}$ & $\begin{array}{l}10.10 .0 . \\
0\end{array}$ & 0.10 .0 .3 & $\begin{array}{l}255.255 .25 \\
5.252\end{array}$ \\
\hline SN 2 & $\begin{array}{l}10.10 .1 .1- \\
10.0 .0 .2\end{array}$ & $\begin{array}{l}10.10 .1 . \\
0\end{array}$ & .3 & $\begin{array}{l}255.255 .25 \\
5.252\end{array}$ \\
\hline SN 3 & $\begin{array}{l}10.10 .2 .1- \\
10.0 .0 .2\end{array}$ & $\begin{array}{l}10.10 .2 . \\
0\end{array}$ & 10. & $\begin{array}{l}255.255 .25 \\
5.252\end{array}$ \\
\hline SN 4 & $\begin{array}{l}192.168 .0 . \\
1- \\
192.168 .3 . \\
254\end{array}$ & $\begin{array}{l}192.168 \\
.0 .0\end{array}$ & $\begin{array}{l}192.168 .3 \\
.255\end{array}$ & $\begin{array}{l}255.255 .25 \\
2.0\end{array}$ \\
\hline SN 5 & $\begin{array}{l}192.168 .4 . \\
1- \\
192.168 .4 . \\
126\end{array}$ & $\begin{array}{l}192.168 \\
.4 .0\end{array}$ & $\begin{array}{l}192.168 .4 \\
.127\end{array}$ & $\begin{array}{l}255.255 .25 \\
5.128\end{array}$ \\
\hline SN 6 & $\begin{array}{l}192.168 .2 . \\
1-\end{array}$ & $\begin{array}{l}192.168 \\
.2 .0\end{array}$ & $\begin{array}{l}192.168 .3 \\
.255\end{array}$ & $\begin{array}{l}255.255 .25 \\
2.0\end{array}$ \\
\hline
\end{tabular}




\begin{tabular}{|c|c|c|c|l|}
\hline $\begin{array}{c}\text { Nom } \\
\text { or } \\
\text { Subn } \\
\text { et }\end{array}$ & $\begin{array}{c}\text { IP Address } \\
\text { yang } \\
\text { tersedia }\end{array}$ & $\begin{array}{c}\text { Address } \\
\text { Networ } \\
\mathrm{k}\end{array}$ & $\begin{array}{c}\text { Address } \\
\text { Broadcast }\end{array}$ & Subnetmask \\
\hline & $\begin{array}{l}192.168 .3 . \\
254\end{array}$ & & & \\
\hline & $\begin{array}{l}192.168 .5 . \\
1-\end{array}$ & & & \\
& 192.168 .5$. & 192.168 & 192.168 .5 & 255.255 .25 \\
SN 7 & 126 & .5 .0 & .127 & 5.128 \\
\hline
\end{tabular}

\section{HASIL DAN PEMBAHASAN}

Simulasi yang didapatkan dari penelitian ini yang dilakukan pada simulasi melalui Packet Tracer untuk setiap routing protocol. Skenario pengujian dilakukan dengan cara sebagai berikut:

a. Delay yang diamati saat paket data dikirimkan ketika traffic sedang sibuk, pengiriman dilakukan dari PC ke PC lain.

b. Untuk mengetahui perbedaan rute yang dilewati, cara yang diterapkan dengan melakukan pengamatan ketika trace route melewati jalur yang sering dilalui oleh paket data saat pengiriman berlangsung, kemudian link diputuskan ketika paket data melewati jalur yang biasa dilalui.

\section{Skenario Pertama}

Proses pertama yang dilakukan yaitu pengujian paket data Internet Control Message Protocol (ICMP) yang dikirimkan ketika traffic sedang bekerja. Pengujian ini dilakukan sebanyak 5 (lima) kejadian dan diproses secara terus-menerus sebanyak 5 (lima) kali diulang. Untuk setiap kejadian ditingkatkan traffic dengan cara penambahan 4 (empat) paket ICMP. Lima kejadian atau kasus tersebut hanya untuk topologi ring yang disimulasikan melalui aplikasi Packet Tracer.

Berikut tabel skenario pengujian pertama yang dilakukan yang ditampilkan seperti tabel dibawah ini.

Tabel 3. Skenario pengiriman paket data

\begin{tabular}{|c|c|c|c|c|c|c|c|c|c|}
\hline \multicolumn{2}{|c|}{ Kasus 1} & \multicolumn{2}{|c|}{ Kasus 2 } & \multicolumn{2}{c|}{ Kasus 3 } & \multicolumn{2}{c|}{ Kasus 4} & \multicolumn{2}{c|}{ Kasus 5 } \\
\hline $\begin{array}{c}\text { Pen } \\
\text { giri } \\
\text { m }\end{array}$ & $\begin{array}{c}\text { Pene } \\
\text { rima }\end{array}$ & $\begin{array}{c}\text { Pen } \\
\text { giri } \\
\text { m }\end{array}$ & $\begin{array}{c}\text { Pene } \\
\text { rima }\end{array}$ & $\begin{array}{c}\text { Pen } \\
\text { giri } \\
\text { m }\end{array}$ & $\begin{array}{c}\text { Pene } \\
\text { rima }\end{array}$ & $\begin{array}{c}\text { Pen } \\
\text { giri } \\
\text { m }\end{array}$ & $\begin{array}{c}\text { Pene } \\
\text { rima }\end{array}$ & $\begin{array}{c}\text { Pen } \\
\text { giri } \\
\text { m }\end{array}$ & $\begin{array}{c}\text { Pene } \\
\text { rima }\end{array}$ \\
\hline $\mathrm{PC}$ & $\mathrm{PC}$ & $\mathrm{PC}$ & $\mathrm{PC}$ & $\mathrm{PC}$ & $\mathrm{PC}$ & $\mathrm{PC}$ & $\mathrm{PC}$ & $\mathrm{PC}$ & $\mathrm{PC}$ \\
0 & 5 & 1 & 2 & 2 & 4 & 4 & 7 & 6 & 5 \\
\hline $\mathrm{PC}$ & $\mathrm{PC}$ & $\mathrm{PC}$ & $\mathrm{PC}$ & $\mathrm{PC}$ & $\mathrm{PC}$ & $\mathrm{PC}$ & $\mathrm{PC}$ & $\mathrm{PC}$ & $\mathrm{PC}$ \\
1 & 2 & 2 & 4 & 4 & 7 & 6 & 5 & 0 & 5 \\
\hline $\mathrm{PC}$ & $\mathrm{PC}$ & $\mathrm{PC}$ & $\mathrm{PC}$ & $\mathrm{PC}$ & $\mathrm{PC}$ & $\mathrm{PC}$ & $\mathrm{PC}$ & $\mathrm{PC}$ & $\mathrm{PC}$ \\
2 & 4 & 4 & 7 & 6 & 5 & 0 & 5 & 1 & 2 \\
\hline $\mathrm{PC}$ & $\mathrm{PC}$ & $\mathrm{PC}$ & $\mathrm{PC}$ & $\mathrm{PC}$ & $\mathrm{PC}$ & $\mathrm{PC}$ & $\mathrm{PC}$ & $\mathrm{PC}$ & $\mathrm{PC}$ \\
4 & 7 & 6 & 5 & 0 & 5 & 1 & 2 & 2 & 4 \\
\hline $\mathrm{PC}$ & $\mathrm{PC}$ & $\mathrm{PC}$ & $\mathrm{PC}$ & $\mathrm{PC}$ & $\mathrm{PC}$ & $\mathrm{PC}$ & $\mathrm{PC}$ & $\mathrm{PC}$ & $\mathrm{PC}$ \\
6 & 5 & 0 & 5 & 1 & 2 & 2 & 4 & 4 & 7 \\
\hline
\end{tabular}

Paket yang diteliti merupakan paket yang pertama dalam tabel 3 atau baris yang berwarna hijau. Paket yang lainnya adalah paket yang dikirimkan untuk meningkatkan traffic pada jaringan. Pengujian terhadap topologi ini, routing protocol yang digunakan yaitu EIGRP dan OSPF. Untuk mengetahui delay yang dihasilkan pada pengujian ini dengan melakukan pembagian 2 waktu. Perbandingan nilai rata-rata delay dengan kasus-kasus kejadian yang digunakan yaitu sebagaimana ditunjukkan berikut ini :

Tabel 4. Rata-rata delay EIGRP dan OSPF

\begin{tabular}{|l|r|r|r|r|r|}
\hline \multicolumn{7}{|c|}{ Perbandingan nilai rata-rata delay (detik) } \\
\hline $\begin{array}{c}\text { Topologi } \\
\text { dan } \\
\text { routing } \\
\text { protocol }\end{array}$ & 1 & 2 & 3 & 4 & 5 \\
\cline { 2 - 6 } & \multicolumn{5}{|c|}{ Kasus } \\
\hline $\begin{array}{l}\text { Ring } \\
\text { EIGRP }\end{array}$ & 0,012505 & 0,01033 & 0,010325 & 0,01008 & 0,010715 \\
\hline $\begin{array}{l}\text { Ring } \\
\text { OSPF }\end{array}$ & 0,01305 & 0,01061 & 0,010715 & 0,010405 & 0,011105 \\
\hline
\end{tabular}

Apa bila nilai delay diproses rata-rata untuk setiap routing protocol terhadap setiap kejadian atau kasus maka akan diperoleh :

a. Topologi Ring untuk Routing Protocol EIGRP

Rata-rata nilai delay untuk routing protocol EIGRP

$$
\begin{gathered}
\frac{0,012505+0,01033+0,010325+0,01008+0,010715}{5} \\
=0,010791 \text { detik }
\end{gathered}
$$

b. Topologi Ring untuk Routing Protocol OSPF

Rata-rata nilai delay untuk routing protocol $O S P F$

$$
\begin{aligned}
\frac{0,01305+0,01061+0,010715+0,010405+0,011105}{5} & 0,011177 \text { detik }
\end{aligned}
$$

Perbandingan nilai routing protocol EIGRP dan routing protocol OSPF adalah nilai routing protocol EIGRP lebih baik 0,010791 detik dari pada routing protocol OSPF

\section{Skenario Kedua}

Proses pengujian ini dilakukan dengan cara melihat router yang dilewati paket data sebelum pemutusan link, lalu memutuskan beberapa link yang dilewati paket tersebut untuk mengetahui perubahan jalur yang dilewati paket data. 
1. Hasil pengujian skenario kedua sebelum pemutusan link

a. Topologi Ring EIGRP

Jalur yang dilewati oleh paket ICMP saat pengiriman paket yaitu paket dikirimkan melalui:

a) Pengiriman berlangsung dari PC0 ke PC5 melewati Switch dari Gedung A diteruskan ke sumber R1 (Router 1), dalam hal ini R1 (Router 1) merupakan sumber router

b) Dari R1 (Router 1) menuju ke R0 (Router $0)$ kemudian dilanjutkan dan berada pada network ke 3 (tiga) yaitu R2 (Router 2),

c) Pada R2 (Router 2) yang bertindak sebagai router tujuan pengiriman dilanjutkan ke switch Gedung C sehingga paket menuju ke penerima PC5.

Perbedaan jalur yang dilalui karena dilakukan oleh parameter nilai metric pada routing protocol EIGRP. Perhitungan nilai metric diambil dari total jalur lalui dari router sumber ke router tujuan dengan persamaan sebagai berikut :

$$
\begin{array}{rl}
\text { metric }=256 & *\left(\frac{10^{7}}{\text { minimum bandwidth }}\right. \\
& \left.+\frac{\text { total delay }}{10}\right)
\end{array}
$$

Penjelasan lebih lanjut tentang nilai metric akan dijelaskan pada gambar 4 sebagai berikut.

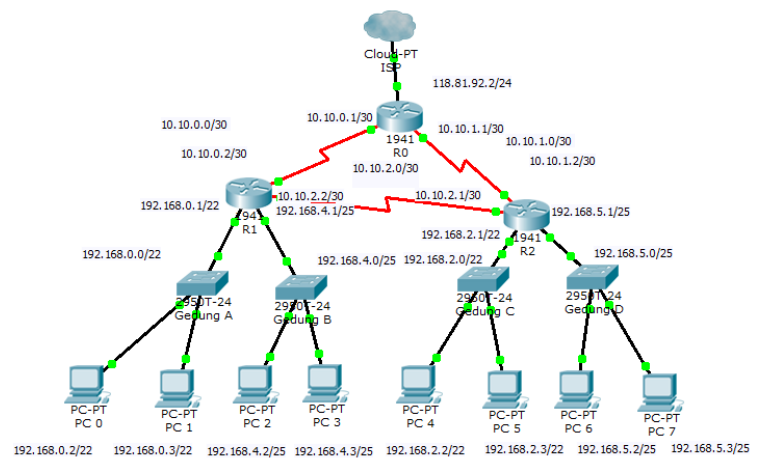

Gambar 4. Pengiriman paket dari R0 menuju R1 topologi Ring EIGRP

Berdasarkan topologi jaringan diatas, jalur yang dilalui saat paket dikirimkan yaitu pengiriman melalui network address di R0 (Router 0) menuju R1 (Router 1) kemudian pengiriman dilanjutkan ke R2 (Router 2) dengan menggunakan bandwidth minimum $100 \mathrm{kbps}$, dilihat dari delay interface serial $20000 \mu s$ dan juga delay interface fast ethernet $100 \mu \mathrm{s}$. Menentukan nilai metric dengan cara sebagai berikut :

$$
\begin{gathered}
\text { metric }=256 *\left(\frac{10^{7}}{100 \mathrm{kbps}}+\frac{20000 \mu \mathrm{s}+20000 \mu \mathrm{s}+100 \mu \mathrm{s}}{10}\right) \\
=26626560
\end{gathered}
$$

Sedangkan jika pengiriman paket dari R0 (Router 0) menuju R2 (Router 2) kemudian dilanjutkan ke R1 (Router 1) dengan bandwidth $50 \mathrm{kbps}$, delay interface serial $20000 \mu \mathrm{s}$ dan delay interface fast Ethernet $100 \mu \mathrm{s}$. Perhitungan nilai metric adalah sebagai berikut :

$$
\begin{gathered}
\text { metric }=256 *\left(\frac{10^{7}}{50 k b p s}+\frac{20000 \mu s+20000 \mu s+100 \mu s}{10}\right) \\
=52226560
\end{gathered}
$$

Dari analisis penentuan nilai metric yang telah dilakukan maka terdapat dengan pembuktian bahwa paket data akan melewati nilai metric 26626560 yang terkecil untuk mencapai ke tujuan dibandingkan melewati nilai metric 52226560 yang lebih besar.

\section{b. Topologi Ring OSPF}

Pengiriman paket data melalui jalur yang dilalui oleh paket ICMP sebagai berikut :

a) $\mathrm{PC} 0 \mathrm{ke}$ PC5

Pengiriman dilakukan mulai dari PC0 menuju Switch dari Gedung A dilanjutkan ke R1 (Router 1),

Dari R1 (Router 1) pengiriman diteruskan ke R0 (Router 0) selanjutnya pengiriman diteruskan lagi ke R2 (Router 2) menuju Switch dari Gedung C kemudian paket dihantarkan ketujuan PC5. Proses ini merupakan jalur yang dipilih oleh $O S P F$ untuk menentukan nilai cost yang berbeda di setiap jalurnya masing-masing, perhitungan nilai cost berdasarkan dari masingmasing interface yang dilewati dari router sumber ke router tujuan dengan perhitungan sebagai berikut :

$$
\text { Cost }=\frac{100 \mathrm{Mbps}}{\text { Bandwidth }}
$$

Perhitungan nilai cost akan dijelaskan dari gambar topologi dibawah ini : 


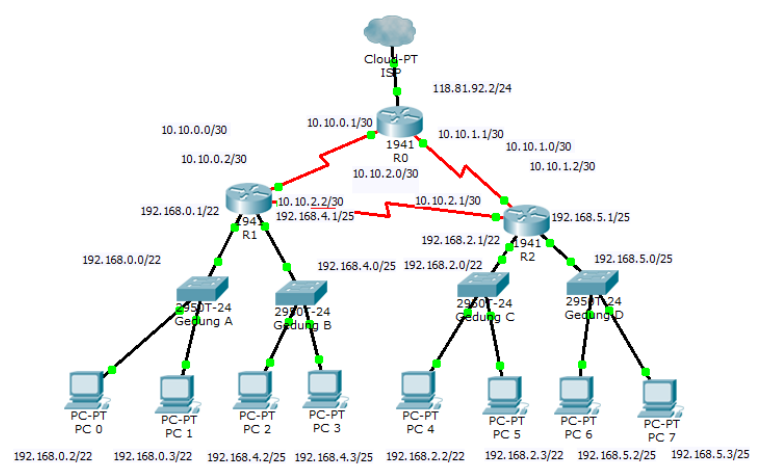

Gambar 5. Pengiriman paket dari R0 menuju R1 topologi Ring $O S P F$

Dari gambar 5 diatas dapat dilihat jalur pengiriman paket dari R0 (Router 0) menuju R1 (Router 1) via R2 (Router 2) dimana bandwidth dari masing-masing interface adalah $100 \mathrm{kbps}$, untuk menentukan nilai cost dengan cara perhitungan dibawah ini :

$$
\begin{aligned}
\operatorname{Cost}(\text { total })= & \frac{100 \mathrm{Mbps}}{100 \mathrm{kbps}}+\frac{100 \mathrm{Mbps}}{100 \mathrm{kbps}} \\
& +\frac{100 \mathrm{Mbps}}{100 \mathrm{Mbps}}=2001
\end{aligned}
$$

Jadi cost interface menuju R1 (Router 1) adalah 2001. Sedangkan jika pengiriman paket dari R0 menuju R2 (Router 2) via R1 (Router 1) dengan bandwidth masing-masing interface 50 kbps, perhitungan nilai cost adalah sebagai berikut :

$$
\begin{aligned}
\operatorname{Cost}(\text { total })= & \frac{100 \mathrm{Mbps}}{50 \mathrm{kbps}}+\frac{100 \mathrm{Mbps}}{50 \mathrm{kbps}} \\
& +\frac{100 \mathrm{Mbps}}{100 \mathrm{Mbps}}=4001
\end{aligned}
$$

Jadi cost interface menuju R2 (Router 2) adalah 4001. Pengiriman paket data akan melewati nilai cost yang terkecil yaitu 2001 dari pada nilai cost yang lebih besar yaitu 4001 berdasarkan dari analisis perhitungan nilai cost seperti yang terdapat diatas.

2. Skenario kedua terhadap pengujian dan memiliki hasil setelah pemutusan link

Pada masing-masing topologi diputuskan jalur yang biasa dilewati oleh paket data ICMP melalui ping dan untuk mengetahui jalur backup yang dimiliki oleh masing-masing routing protocol. Pemutusan jalur seperti jalur yang menghubungkan antara R0 (Router 0) ke R2 (Router 2). Adapun hasilnya seperti berikut :

\section{a. Ring Topologi EIGRP}

Ketika route link diputuskan saat pengiriman paket dari PC0 ke PC5 dan jalur yang dilewati yaitu :

1) Dari PC0 melalui Switch Gedung A dan diteruskan ke R1 (Router 1),

2) Selanjutnya pengiriman diteruskan dari R0 (Router 0) ke R2 (Router 2) dan diteruskan dari Switch Gedung C sampai tujuan ke PC5.

Pengiriman paket data memiliki nilai metric 52226560 dengan jalur yang dilewatinya.

\section{b. Ring Topologi OSPF}

Setelah route link diputuskan saat paket dikirimkan dari PC0 ke PC5 dan jalur yang dilewati yaitu :

1) Dari PC0 melewati Switch Gedung A dan dilanjutkan ke R1 (Router 1),

2) Kemudian pengiriman dilanjutkan ke R0 (Router 0) diteruskan ke R2 (Router 2) dan melewati Switch Gedung C sampai ke tujuan PC5.

Paket yang dikirimkan melewati jalur dengan nilai cost 4001 .

\section{Skenario Ketiga}

Dari proses pengujian tahap ketiga ini yaitu waktu konvergensi karena akan diamati setiap router akan mendapatkan informasi dari router lain dan siap melakukan pengiriman paket data.

1. Ring Topologi EIGRP ketika Waktu Konvergensi

Proses "show ip EIGRP neighbors" merupakan salah satu cara melihat dan mengetahui konvergensi Ring EIGRP pada router CLI Command dengan hasil sebagai berikut :

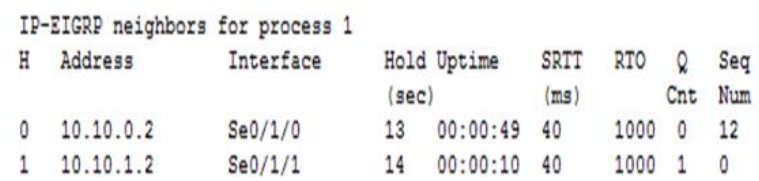

Gambar 6. Simulasi Topologi Ring EIGRP Hasil Waktu Konvergensi

Dimana kolom Hold (sec) menunjukkan Hold Time pada router dan proses ini juga untuk menunggu packet Hello dari router yang lain. Kejadian inilah disebut dengan waktu konvergensi disetiap router. Nilai default hello interval 5 detik dan Hold/Dead interval secara 
default yaitu 15 detik. Sehingga rata-rata konvergensi untuk setiap router adalah :

$$
\begin{aligned}
& \text { Waktu Konvergensi Rata - rata } \\
& =\frac{13+14+14}{3} \\
& =13,66 \text { detik }
\end{aligned}
$$

\section{Ring Topologi OSPF saat Waktu}

Konvergensi

Pada "show ip OSPF neighbors" salah satu cara melihat dan mengetahui convergensi time di topologi $O S P F$, dimana perintah tersebut

\begin{tabular}{|c|c|c|c|}
\hline ID & Pri State & Dead Time & Addeesg \\
\hline 118.81 .9 & $0 \quad 500 / 1-$ & $00: 00: 33$ & 10.10 .0 .1 \\
\hline 192.168. & $0 \quad 5002 /$ - & $00: 00: 31$ & 10.10 .2 .1 \\
\hline
\end{tabular}
dapat dilakukan di CLI Command disetiap router dengan hasil sebagai berikut :

Gambar 7. Waktu konvergensi hasil simulasi topologi Ring OSPF

Pada kolom pemetaan hasil seperti yang tertera akan dijelaskan dead time. Kolom pemetaan hasil waktu konvergensi topologi OSPF menunjukkan nilai Dead Time pada router sewaktu menunggu packet Hello dari router lain. Secara default nilai Hello interval yaitu 10 detik dan Hold/Dead interval 40 detik. Dari nilai tersebut maka diperoleh nilai rata-rata convergensi time dari setiap router sebagai berikut :

$$
\begin{aligned}
& \text { Waktu Konvergensi Rata - rata } \\
& =\frac{30+33+37}{3} \\
& =33,33 \text { detik }
\end{aligned}
$$

\section{SIMPULAN DAN SARAN}

\section{Kesimpulan}

Perbandinagn topologi EIGRP dan OSPF setelah dilakukan pengujian maka diperoleh hasil yang dijelaskan pada kesimpulan seperti berikut ini :

a. Diketahui nilai delay total topologi EIGRP lebih baik $386 \mu$ detik dibandingkan nilai dengan nilai delay pada topologi OSPF.

b. Topologi OSPF bersifat link state sehingga saat pengiriman paket yang sama dengan nilai cost yang sama maka akan dikirimkan tidak hanya pada rute terpendek tapi juga rute terpanjang. c. Convergensi time nilai rata-rata yang diperoleh pada topologi EIGRP yaitu 12,75 detik sedangkan topologi OSPF yaitu 35,25 detik.

d. Waktu dead interval topologi EIGRP adalah 15 detik sedangkan topologi $O S P F$ adalah 40 detik sehingga convergensi time topologi EIGRP lebih cepat dibandingkan topologi OSPF.

\section{Saran}

Penelitian tentang perbandingan kinerja antara topologi EIGRP dengan topologi OSPF masih banyak memiliki kekurangan maka penulis kali ini memberikan beberapa saran sebagai berikut :

a. Penelitian routing protocol EIGRP dan routing protocol OSPF yang dibuat dapat dilakukan pengembangan seiring berjalannya teknologi informasi sehingga bisa memperoleh hasil yang lebih baik

b. Pemanfaatan simulator jaringan komputer sangat mendukung dalam merancang sebuah jaringan komputer sebelum membangun jaringan komputer secara real.

\section{UCAPAN TERIMA KASIH}

Pada kesempatan ini penulis menyampaikan penghargaan dan penghormatan kepada semua pihak yang telah membantu dan menyelesaikan penelitian ini, ucapan terima kasih disampaikan kepada :

1. Rektor Universitas Bumigora Mataram yang telah mendukung dan memberikan motivasi dalam penyelesaian penelitian ini.

2. Kepala LP2M Universitas Bumigora Mataram yang selalu menyampaikan informasi terkait penelitian dan membantu dalam publikasi

3. Bapak/Ibu dosen Universitas Bumigora Mataram yang telah mendukung dan membantu dalam penyelesaian penelitian ini.

\section{REFERENSI}

[1] A. Setiawan and N. Sevani, "PERBANDINGAN QUALITY OF SERVICE ANTARA ROUTING INFORMATION PROTOCOL ( RIP ) DENGAN OPEN SHORTEST PATH FIRST ( OSPF )," pp. 196-207.

[2] E. Menggunakan, S. Jaringan, and O. Modeler, "SIMULASI KINERJA ROUTING PROTOKOL OPEN 
SHORTEST PATH FIRST (OSPF) DAN ENHANCED INTERIOR GATEWAY ROUTING PROTOCOL (EIGRP) MENGGUNAKAN SIMULATOR JARINGAN OPNET MODELER V. 14.5," pp. 1-6.

[3] Azhar, R. (2015). ANALISA PERBANDINGAN PENERAPAN PBR DAN NON PBR PADA PROTOCOL OSPF UNTUK KONEKSI INTERNET. MATRIK : Jurnal Manajemen, Teknik Informatika Dan Rekayasa Komputer, 15(1), 29-34.

[4] "Pengembangan Jaringan Komputer Universitas Surakarta Berdasarkan Perbandingan Protokol Routing Information Protokol (RIP) Dan Protokol Open Shortest Path First (OSPF) Prawido Utomo, Bambang Eka Purnama ABSTRAKSI," vol. 1, no. November, pp. 8-25, 2012.

[5] "DESAIN IMPLEMENTASI ROUTING JARINGAN KOMPUTER," vol. 3, no. 1, 2009.

[6] B. A. Y. Tampi, M. E. I. Najoan, A. A. E. Sinsuw, A. S. M. Lumenta, and A. P. J. Komputer, "Implementasi Routing Pada IP Camera Untuk Monitoring Ruang di Universitas Sam Ratulangi," pp. 1-8, 2013.

[7] Wiji Suhardjo, Bambang Eka Purnama (2013), Pemanfaatan Local Area Network Dan Program Netop School Sebagai Media Pembelajaran Interaktif Pada Jurusan Teknik Komputer Jaringan Smk $N 1$ Klaten, IJNS - Indonesian Journal on Networking and Security, Vol 2 No 3 Juli 2013, ijns.org, ISSN: 2302-5700 